\title{
A Study of Metaphor and Metonymy in Lacan
}

\author{
Dirk De Schutter \\ Georgetown University
}

In this paper I want to set forth and explain the linguisitc theory of the French psycho-analyst Jacques Lacan. More concretely. I want to show how Iacan's theory revolutionizes the traditional (metaphysical) understanding of metaphor and metonymy and what the role of language, of metaphor and metonymy, is in Lacan's psycho-analysis.

Like so many structuralists and post-structuralists, like so many thinkers in Erance, Lacan goes back to the Swiss linguist of the beginning of the twentieth century. Ferdinand de Saussure. Lacan's linguistic theory originates in a reading of de Saussure's cours de linguistique générale, a reading that at. the same time radicalizes de Saussure's insjghts. If one reads de Saussure in a certain way, language becomes a game of differences. What follows is a reading of de Saussure as it is found in some of Lacan's texts (a reading, by the way, that someone like Jacques Derida will at least partially subscribe to).

A word, a linguistic sign establishes the union of a sound (an acoustic image) and a concept (a mental image). The relation between these two, between the signifier and the signified, is arbitrary. There is no reason whatsoever why the sound 'tree' [Ff:.] would evoke the concept 'tree'. The signified 'tree' could be represented by any other signifying sound. To prove this, de Saussure refers to the different languages: for example, the signified 'tree' has the English signifier $\mid \mathrm{F}\{i . \mid$ and the Dutch signifier $\mid$ bo.m $]$. Both signifiers serve equally well to signify the concept 'tree'.

This arbitrariness in the relation between signifier and signified causes the strange plienomenon that each element of language cannot be determined in isolation from the others: one cannot derive the signified froin the acoustic signifier, nor can one induce the signifier from the signified concept. The elements of a language can only be determined through the network of relations to which they belong. Like the pieces in a game of chess, the elements of language do not have a content or a meaning of their own; they only have a 
meaning on the basis of their mutual relations, or insofar as they possess a value in a system or structural network.

The elements of language do not have a positive content of their own; they only have a value insofar as they differ from other elements. The value of elements can only be determined in a negative way, i.e.. through the relation with other elements in the system. Each element is only what the other is not. This holds true for both signifier and signified. The signified 'car' gets determined chrough its difference from other signifieds like 'chariot', wagon', 'van', 'sleigh', etc. Similarly, the signifier ' $t$ ' only signifies in the sign 'cat' because it thakes that sign differ from signs like 'cap'. 'cab', 'can', etc.

The foregoing does away with a lot of the traditional concepts and insights. The signified is no longer an extra-textual, transcendental "idea" that, sufficient in itself, precedes every lingual constitution and waits for an expression by a signifier. It can only be determined in a negative way. It has become an effect of the signifying game of differences. The signifier can no longer be thought of as the vehicle of a signifying element. It has become an instance that distinguishes sigmification and that does not have any signification in itself. It produces signification through ite difference from other signifiers. A third consequence of the Lacanian way of reading de Saussure is the lack of a pre-established correspondence between the order of the signifier and the order of the signified. Language is a system of differences, in which the immediate link between signifier and signified has disappeared.

With these insights we can try to understand the Lacanian algorithms for the linguistic sign. Lacan depicts the sign as follows: ' $f+(S) \frac{1}{5}$ '. Here the signifier s creates a meaning, but it can only do so thanks to its relation with other signifiers; it needs the complementation of other signifiers that can appear in the place kept open by 1 , in order to (fully) signify $s$. Or to put it differently, the meaning 's' does not get signified by the signifier $s$; there is always a difference between $S$ and $s ; s$ has been delayed; a detour via other signifiers is needed, and even then $s$ will always withdraw and never become fully present.

And there is more. If the signified is understood as an effect of the signifying chain, and if this effect can be delayed, the signified is ultimately nonexistent. There is no transcendental "idea" beyond the chain of signifiers that could bring the signifying chain to a halt. All signification is provisional; ultimately, the signified is itself of the order of the signifiers. 
These linguistic insights Lacan combines with the psychoanalytic theory of the "Urverdrängung." The sign in which the difference between signifier and signified is never really overcome, mirrors the breach in reality brought about by language. The primal repression constitutes the unconscious in that it pushes back into the unconscious the original symbiotic union of child and mother. This imagined union of the child with its mother is forever delayed in the primal repression that is caused by the child's access to language and fully achieved by its passage through the oedipal triangle. In appropriating language the child tries to master the mother's absence: this is the meaning Lacan gives to the "Fort-Da" episode in Freud's "Jenseits vom Lustprinzip." In uttering the phonemes $0-A$ the child shows its awareness of the mother's successive presence and absence. It also proves that it knows the mother as different from itself; in symbolising the mother's disappearance it discovers the mother as the desired object. This is the paradox of the whole situation: in an attempt to symbolise the mother's presence in words, the child loses the union with its mother for ever. From now on, it can only approach its mother through the mediation of language. An immediate union is irrecuperably lost. "Ainsi le symbole se manifeste comme meurtre de la chose."

The child's access to language and the primal repression as loss of the immediacy is compleced in the oedipal constellation, through which the child takes on the phallus as a signifier. In the acceptance of the Name-of-the-father, the child recognizes its desire. In recognizing its destre, the child also renounces it. originally, the infant desires to be the phallus, i.e.. desires to be the object of the mother's desire. But in subjecting itself to the Naute-of-the-father, and the law it incarnates, the child assumes itself, i.e., its own lack--it names this lack and as such takes on the symbol that signifies it. In this way, the primal repression is at the same time a repression of the paradise of immediacy and of the symbolic order forever intervenes in the desired union. Consequently, the "Urverdrängung" is the fall of the first signifier (the phallus) and causes the unconscious to be structured like a language. Language is not at the free disposal of the subject; on the contrary, the subject can only be subject if he subjects himself to the laws of language. The subject is "serf du langage" ${ }^{2}$ it is not the subject who uses language as an "organon," but language speaks through him as persona. "Die Sprache spricht. Der Mensch spricht, insofern er der sprache entspricht." This is why Lacan can claim that the unconscious laws that govern man are linguistic rules. The Institution of the subject is determined "by the absolute play of combination and substitution in the 
signifier, according to the two aspects that generate the signified, metonymy and metaphor."

Lacan formulates the metonymy as follows: 'f $\left(s . . . s^{\prime}\right) s \cong s(-) s^{\prime}$.

\begin{abstract}
"indiquant que c'est la connexion du signifiant au signifiant, qui permet l'élision par quoi le signifiant installe le manque de l'être dans la relation d'objet, en se servant de la valeur de renvoi de la signification pour l'investir du désir vivant ce manque qu'il supporte."s
\end{abstract}

The metonymy is constituted in a horizontal, syntagmatic expansion of signifiers: this expansion makes a movement from $S$ to $S^{\prime}$. In itself this movement is endless: ever new signifiers can be added, the concatenation will never be fulfilled. This possibility of an endless concatellation proves that the signifiers are in lack of a transcendental, extra-lingual presence that would be able to stop the movement and to round off the signifying process. The yap between reality and language can never be bridged. The mediation language has brought about (opens up) an emptiness. The subject wants to fill up this emptiness with words, but as every word is itself an effect of this enptiness and carries at its centre the very gao between signifier and siqnified, it can only increase the emptiness it tries to overcome. As such the completion of $S$ by $S^{\prime}$ remains incomplete--other signifiel:s are needed to fill up the emptiness. The metonymy shows that at least one signifier is always short and that every attempt to signify is limited and in need of completion.

Moreover, metonymy is not only a characteristic of language in its full possibilities, but actual speech itself adds to this metonymic pattern. In speech one can never actualize all the possible signifiers (S..... $S^{\prime}$ ), one must always leave something out. In actualizing $s$, one drops $s^{\prime}$, although $s$ is jn need of $s^{\prime}$. of course, the virtual connection of $s^{\prime}$ to $s$ stili liclds, but the elision of $s^{\prime}$ can do nothing but maximize the emptiness it is silpposed to surmount. Precisely because there is an unconquerable distance between language and reality, the bar between signifier and signified is maintained. This is the meaning of ' $s(-) s^{\prime}$ in the formula given above.

Whereas metonymy emphasizes the incessant sliding of signifiers and the delaying of a fixed signified, metaphor is the structure that allows the emergence of signification. The Lacanian formulation of the metaphorizing process runs as follows if $\left(\frac{5^{\prime}}{5}\right) \mathrm{s} S \mathrm{~S}(+) \mathbf{s}^{\circ}$, "indiquant que $c$ 'est dans la substitution du signifiant au signifiant que se produit un efiet de signification." Originally, the signifier $s$ is a latent signifier with respect to $S^{\prime}$. $S$ is one of the innumerable 
signifiers $S^{\prime}$ refers to or is connected with. Indeed, every signifier has a whole set of other signifiers attached to itself vertically (on the paradigmatic axis).' If $S$ is actualised and brought up above the bar. $S$ ' gets a new signification--the $'(+)^{\prime}$ in the formula. This substitution of $S$ for $S$ ' is only possible because $S^{\prime}$ does not have a fixed or proper meaning. The substituting process that takes place between the two signifiers can in no way be reduced to or grounded in the availability of a prior given meaning.

In the metaphor a signifier is substituted for another. S takes the place of $\mathbf{s}^{\prime}$. Originally, $\mathbf{s}$ was only a possible signified of $s^{\prime}$; now, it becomes the actual signifier instead of $S^{\prime}$. The positive difference between $s$ and $S^{\prime}$ founds a new signification, in the formula' $(+) s$ '. The metaphor realizes the crossing of the bar between signifiers and signified (that is also from the order of the signifier) and so forms a momentary stop in the incessant sliding of signifiers. It is this crossing of the bar and fixing of signifiers in the signifying chain that allows for a creation of meaning. The signifying movement gets a rest and the emptiness the horizontal expansion tried to overmaster in vain gets a preliminary identification.

According to Lacan's disciples, Jean Laplanche and Serge Leclaire, this moment of metaphorizing fixation can be linked to Lacan's rotion of the anchoring point:

". . the 'pinning down' I speak of, or the point de capiton. is mythical, for no one has ever been able to pin a signification on a signifier; but on the other hand what can be done is to pin one signifier to another signifier and see what happens. But in this case something new is invariably produced.. . in other words, the surging forth of a new signification..." "

Perhaps the identifying power of the metaphor becomes clearer in Lacan's formula of the paternal metaphor: ' $\frac{S}{5} \cdot \frac{S^{\prime}}{\rightarrow} S\left(\frac{1}{5}\right)^{\prime} .10 \mathrm{~S}$ is implanted in the signifying chain: the $S^{\prime}$ that $S$ is substituted for falls to the level of the signified. S almost looks like an intruder in the signifying chain, since one does not know where it comes from. But it is precisely this unpredictable newness that explains both the "superfluite radicale de toute signification"'l and Lacan's saying that there is no predestination for this "fonction de phore". 12 Due to the difference between $S$ and $S^{\prime}$. the unknown signified of $s$ ' which is ' $x$ ', is offered a new meaning. But on the other hand, every implantation of a signifier $s$, every attempt to identify $x$ is preliminary. The identifying process can go on for ever (on the place kept open by 1) such that every new signifier will only give a partial meaning to $x$. 
More specifically, what happens in the oedipal triangle is that the child who enters the game as a dead subject $(x)$ receives a name and an identity. What is signified to him is that the desire of the mother ( $\mathrm{s}^{\prime}$ ) has as its real signifier the Name-of-the-father (S) as bearer of the phallus." As a consequence of the acceptance of the paternal metaphor, the child renounces his desire to be the phallus. Ihe law of the father cuts off the child from the mother, breaks off the dual union (castration) and thus makes the child accede to real desire in accordance with the order prescribed by the law--the child comes to know that it can have a phallus, like his father. This identification is not a congruency, like the imaginary identification in the mirror-stage, since there remains a difference between child and father, in the formula 's $\left(\frac{1}{5}\right)^{\prime}$. In order to become himself, the child will need other gignifiers.

Lacan underlines this unending process by equating the subject to the mathematical zero. "Insofar as the primary signifier is pure non-sense, it becomes the bearer of the infinitization of the value of the subject, not open to all meanings, but abolishing them al1, which is different." "If the phallus as the primary repressed signifier comes to zero, the consequent in the implication of the paternal uetaphor ' $\left(\frac{2}{5}\right)$ ' becomes ' $S\left(\frac{1}{\frac{1}{0}}\right)$ ' or ' $S \infty$ ' $^{\prime}$. The subject needs all infinite alnount of signifiers in order to give meaning to himself. Each signifier that will be offered to signify the repressed primal signifier, as the signifier of the subject's desire, will turn out to be insufficient and only provisional. After a while, it will be rejected. Every identification it will make possible will be undone ill the neturymic desire for new signifiers.

The metaphor as fixation of the signifying chain identifies the emptiness, that, ultimately, is nothing but the subject itself as the open place between language and reality, as the gap in language, as the hole in the universal discourse. As identification of the subject as zero, the metaphor gives meaning to the repressed primal signifier--the phallus. It is to the phallus as primary signifier and its rhetorical games that the subject must subject himself. Ihat is why the metaphor, insofar as it succeeds in identifying the phallus and in creating signification, is a symptom. "C'est dire que la réalité la plus sérieuse, et même par l'homme la seule sérieuse, si l'on considère son rôle à soutenir la métonymie de son désir, ne peut être retenue que dans la métaphore." 1 s

Indeed, whereas the function of the metaphor is to give new meaning to the phallus as signifier of desire. metonymy serves as that structure that annihilates every definition and feeds the insatiability of desire. 
Metonymy as the endless chain of signifiers, always on the move, is desire itself. That is the other thing the child gets to know in the oedipal triangle, i.e.. being cut off from his mother, the dual union is forever delayed. The Name-of-the-father as law and symbolic order confronts the child with its own lack. In identifying with the father the child accedes to language but also establishes the unsurmountable difference. In language desire becomes a real desire, something that will never be fulfilled. The desired object ran only be approached through a metonymical chain. "Ainsi le symbole se manrfeste d'abord comme meurtre de la chose, et cette mort constitue dans le sujet l'éternisation de son désir."

Through the castration the child ceases to be a zero and is offered the opportunity to become some-one. At first, the child desired to be one with the mother; this undifferentiated identity is, however, meaningless. It is nothing. The child can only get an identity if it knows itself as different from the mother--difference is the necessary condition for identity. But once this difference is brought about, the oneness with the mother call never be accomplished. The oneness with the mother is broken up, and the selfidentity becomes visible as a difference from others. In this sense, the phallus is both the "signifier par excellence of the impossible identity Iwith the motherl"1' and the signifier of the impossibility of the total personality. Language not only enternalizes the subject's desire for union with the mother, it also defers (differs) the subject's own identity in submitting him to the endless play of metonymy and metaphor.

This is the play language has written. The subject enters it as actor in the oedipal mise-en-scène. In obeying the law of the father, the subject ceases to be the phallus and accepts the possibility of having a phallus. As such, he becomes a "want-to-be", "un manque à être." As long as one is the phallus, one is zero, one cannot become a subject. As suon as one has the phallus, one lacks and is in desire--one is underway to being (a subject). This is the meaning of another Lacanian oracle about the phallus as "le seul objet dont $l^{\prime}$ avoir nécessite le manque à l'être."1"

This seems to be the outçome of the formula Lacan gave of the oedipal complex $\frac{5}{5} \cdot \frac{s}{x} \rightarrow s\left(\frac{1}{5}\right)^{\prime}$. He calls it the formula of the paternal metaphor. The foregoing seems to suggest that metaphor and metonymy belong together: metaphor as identification and fixation, metonymy as eternalisation and endless sliding. Could one therefore not say that the oedipal complex is the installation of both metaphor and metolrymy?

Indeed, for the paternal metaphor to succeed, the child first has to be displaced. This displacenent is the breaking up of the dual union and, as metonymical 
move, triggers off the eternal desire for the irrecuperably lost object. But the father not only castrates, he also offers the child a possible identification. In this way, metonymy and metaphor can perhaps be connected with the two functions of the father's presence--castration and promise."

The same opposition can be found in Jacques Derrida's article "Le retrait de la métaphore." For him every inetaphysics is a metaphor in that it tries to give a name to the unnameable par excellence, Being (das Sein). As such, all metaphysical names for Being are metaphors: EIDOS, substantia, monad, ground, will. Being always retreats, it withdraws--there is no full unconcealment in metaphysics. Every metaphysical name leaves much unsaid and unthought. "On serait alors tenté de dire: le(sic) métaphysique, qui correspond en son discours au retrait de l'être, tend à rassembler, dans la ressemblance, tous ses écarts métonymiques dans une grande métaphore de l'être ou de la pensée de l'etre. Ce rassemblement est la lanque de la métaphysique."

Such is the game Being or Logos plays: a Saussurian chessgame or a Heraclitian game of draughts. In this game man is needed for the "lente mutation de l'être dans 1' EN PANTA du langage." 2 s Asking why there is a play or what is being played for, one should (and is afraid to) remember the words of Novalis: "Gerade das Eigentümliche der Sprache, dass sie sich bloss um sich selbst bekümmert, weisz keiner."22

\section{NOTES}

I"Thus the symbol manifests itself as the murder of the thing." J. Lacan, "Fonction et chamn de la parole et du langage en psycanalyse," in "Ecrits I, (Paris: Seuil, 1966), p. 204. "The Function and Field of Speech and Language in Psychoanalysis," in kicrits. A Selection, translated by A. Sheridan, (New York: Norton, 1977). p. 104.

2 "The slave of language." J. Lacan, "L'instance de la lettre dans l'incorscient," in Ecrits I. (Paris: Seuil, 1966), p. 251. "The Agency of the Letter in the Unconscious or Reason Since Ereud," in Ecrits. A Selection, p. 148 .

"Language speaks. Man speaks, insofar as he corresponds to language." $M$. Heidegger, Unterwegs zur Splache, (Neske, Pfullingen), 1965 (3), p. 32-33. 
"J. Lacan, "The Signification of the Phallus," in Ecrits. A Selection, p. 285.

"Indicating that it is the connection between signifier and signifier that permits the closing by which the signifier installs the lack of being in the object relation, using the value of reference-back possessed by signification in order to invest it with the desire aimed at the very task it supports." J. Lacan, idem (2), p. 274; p. 164 .

"Indicating that it is in the substitution of signifier for signifier that an effect of signification is produced." J. Lacan, idem (5).

'J. Lacan, idem (2), p. 261; p. 154.

'J. Lacan, "The Subversion of the Subject and the Dialectic of Desire in the Freudian Unconscious," in Ecrits. A Selection, pp. 292-326.

'A. Wilden, The Language of the Self, (Baltimore/ London: Johns Hopkins Press, 1973) (2), p. 274.

$10 \mathrm{~J}$. Lacan, "On a Question Preliminary to Any Possible Treatment of Peychosis," in Ecrits. A Selection, p. 200 .

"l"radical superfluousness of all signification." J. Lacan, idem (2), p. 265; p. 157 .

12J. Lacan, "La métaphore du sujet," in Ecrits. (Paris: Seuil, 1966), p. 890.

'A. De Waelhens, Schizophrenia, translated with introduction, notes and bibliography by $W$. Ver Eecke, (Pittsburgh: Duquesne University Press, 1978), p. 127.

"J. Lacan, The Eour Eundamental Concepts of Psychoanalysis, translated by A. Sheridan; edited by $J$. A. Miller, (New York: Norton, 1978), p. 252.

1s"That is to say that the most serious reality. and even for man the only serious, can only be retained in metaphor given its role in maintaining the metonomy of this desire." J. Lacan, idem (12), p. 892.

16 "Thus the symbol manifests itself as the murder of the thing and this death constitutes in the subject the eternalization of his desire." J. Lacan, idem (1).

'A. Lemaire, Jacques Lacan, translated by D. Macey, (London,Boston: Routledge and Kegan Paul, 1977), p. 86 . 
1" "The only object the having of which necessitates the want to be." J. Lacan, Idem (15).

19A. De Waelhens, idem (13), p. 21.

20"One would then attempt to say: metaphysics, which corresponds in its discourse to the withdrawel of being, tends to gather, in the similarity, all its metonymical arguments into one great metaphor of being or of the thought of being. This gathering is the language of metaphysics." J. Derrida, "Le retrait de la métaphore," in Poesie, n. 7, (1978), p. 116.

2"Slow mutation of being in the En Panta of language." J. Lacan, idem (2), p. 261; p. 154.

22 "Nobody knows just the unique thing about language, that it itself only concerns itself." $M$. Heidegger, Unterwegs zur Sprache, p. 241. 